\title{
HUBUNGAN ANTARA MINAT MASUK JURUSAN D III KEBIDANAN DAN MOTIVASI BELAJAR DENGAN PRESTASI BELAJAR
}

\author{
Laras Miftahul Janaty, Faulia Mauluddina \\ Program Studi DIV Kebidanan STIKES Mitra Adiguna Palembang \\ Komplek Kenten Permai Blok J No 9-12 Bukit Sangkal Palembang 30114 \\ Email : Larasmiftahul98@gmail.com, faulia.mauluddina@gmail.com
}

\begin{abstract}
Abstrak
Menurut data Kementrian Pendidikan Nasional, Jumlah perguruan tinggi yang berada dibawah binaan Kementrian Kesehatan dan Kemendiknas terdapat 729 perguruan tinggi yang menyelenggarakan Program Studi Kebidanan. Minat adalah memahami keinginan dan kecenderungan yang betul-betul dapat terjangkau. Motivasi merupakann dorongan mental yang menggerakkan dan mengarahkan perilaku manusia, termasuk perilaku belajarPrestasi belajar ialah hasil belajar berdasarkan perbedaan tingkah laku sebelum dan sesudah belajar. Tujuan penelitian untuk mengetahui Hubungan Antara Minat Masuk Jurusan D III Kebidanan dan Motivasi Belajar dengan Prestasi Belajar Mahasiswa. Penelitian ini menggunakan pendekatan kuantitatif, jenis penelitian cross sectional. Populasinya semua mahasiswa semester IV program studi D III Kebidanan di Stikes Mitra Adiguna Palembang. Sampel penelitian seluruh mahasiswa semester IV program studi D III Kebidanan di Stikes Mitra Adiguna berjumlah 52 orang. Ada hubungan antara minat masuk jurusan dengan prestasi belajar mahasiswa dengan ( $p$ value = 0,002). Ada hubungan antara motivasi belajar dengan prestasi belajar dengan(pvalue =0, 013). Minat masuk jurusan dan motivasi belajar merupakan faktor yang berpengaruh terhadap prestasi belajar mahasiswa di Stikes Mitra Adiguna Palembang Tahun 2019. Dengan adanya minat dan motivasi belajar yang tinggi akan membuat mahasiswa mendapatkan hasil belajar yang baik.
\end{abstract}

\section{Kata Kunci $\quad$ : Minat Masuk Jurusan, Motivasi Belajar, Prestasi Belajar Bahan Bacaan : $18(2003-2016)$}

\begin{abstract}
According to data from the Ministry of National Education, there are 729 universities under the guidance of the Ministry of Health and the Ministry of National Education that hold Midwifery Study Programs. Interest is understanding what are perfectly accessible desires and tendencies. Motivation is a mental drive that drives and directs human behavior, including learning behavior. Learning achievement is the result of learning based on differences in behavior before and after learning. The research objective was to determine the relationship between interest in entering the D III Midwifery Department and Learning Motivation with Student Achievement. This study uses a quantitative approach, this type of research is cross sectional. The population is all semester IV students of the Midwifery D III study program at Stikes Mitra Adiguna Palembang. The research sample of all semester IV students of the D III Midwifery study program at Stikes Mitra Adiguna totaled 52 people. There is a relationship between interest in entering the department and student achievement ( $p$ value $=0.002)$. There is a relationship between learning motivation and learning achievement with (pvalue =0, 013). Interest in the department and learning motivation are factors that influence student achievement at Stikes Mitra Adiguna Palembang in 2019. High interest and motivation will make students get good learning outcomes.
\end{abstract}

Keywords $\quad$ : Interests in the Department, Learning Motivation, Learning Achievement Reading Material : $18(2003-2016)$ 


\section{PENDAHULUAN}

Pendidikan adalah usaha sadar dan sistematis yang dilakukan oleh orang-orang yang diserahi tanggung jawab untuk mempengaruhi peserta didik agar mempunyai sifat dan tabiat sesuai dengan cita-cita pendidikan. Undang-undang sistem Pendidikan Nasional No. 20 Tahun 2003 menyatakan, bahwa tujuan pendidikan nasional adalah mencerdaskan kehidupan bangsa dan mengembangkan manusia Indonesia seutuhnya yaitu manusia yang bertaqwa terhadap Tuhan Yang Maha Esa dan berbudi luhur, memiliki pengetahuan dan keterampilan, kesehatan jasmani dan rohani, kepribadian yang mantap dan mandiri serta tanggung jawab kemasyarakatan dan kebangsaaan (UU Diknas : 2003).

Pendidikan menurut UNESCO meliputi empat pilar yaitu, Learning to know (belajar mengetahui), Learning to do (belajar melakukan sesuatu), Learning to be (belajar menjadi sesuatu), Learning to live together (belajar hidup bersama) (Maulana, 2010).

Bidan merupakan salah satu tenaga kesehatan yang memiliki posisi penting dan strategis terutama dalam penurunan Angka Kematian Ibu (AKI) dan Angka Kematian Bayi (AKB). Bidan memberikan pelayanan kebidanan yang berkesinambungan dan paripurna, berfokus pada aspek pencegahan, promosi dan berlandasakan kemitraan dan pemberdayaan masyarakat bersamasama dengan tenaga kesehatan lainnya untuk senantiasa siap melayani siapa saja yang membutuhkannya, kapan dan dimanapun dia berada (Keputusan Menteri Kesehatan No. 369, 2007).
Realita yang ada bidan sebagai mitra perempuan merupakan profesi yang memiliki pekerjaan kompleksitas dan tanggung jawab yang besar untuk menyiapkan bidan yang tanggap terhadap situasi terkini dan dapat mengatasi berbagai situasi kompleks yang dihadapi perempuan sepanjang siklus kehidupannya tentu dibutuhkan bidan yang mampu berfikir kritis, analisis-sintesis, kepemimpinan yang hanya dapat dihasilkan oleh sistem pendidikan tinggi kebidanan yang berkualitas dan mampu berkembang sesuai kebutuhan kemajuan zaman (Ikatan Bidan Indonesia dan Asosiasi Institusi Pendidikan Kebidanan Indonesia, 2012).

Seiring dengan meningkatnya ilmu pengetahuan, tekhnologi, dan kebutuhan masyarakat akan pelayanan kebidanan, bidan berkewajiban pula untuk meningkatkan pengetahuan dan keterampilan sesuai dengan perkembangan ilmu pengetahuan dan tekhnologi. Salah satu upaya yang dapat ditempuh bidan adalah dengan cara mengembangkan kariernya meliputi karier fungsional dan karier struktual (Yulifah, 2013).

Berdasarkan Keputusan Menteri Kesehatan No. 369 (2007), tentang standar profesi bidan disebutkan kualifikasi pendidikan bidan yaitu lulusan pendidikan bidan sebelum tahun 2000 dan Diploma III Kebidanan, merupakan bidan pelaksana yang memiliki kompetensi untuk melaksanakan praktiknya baik di institusi pelayanan maupun praktek perorangan.

Pendidikan kebidanan saat ini sudah sangat banyak dan mudah ditemukan, berdasarkan data jumlah 
perguruan tinggi yang berada dibawah binaan Kementrian Kesehatan dan Kemendiknas terdapat 729 perguruan tinggi yang menyelenggarakan Program Studi Kebidanan jenjang D III (Kementrian Pendidikan Nasional, 2011).

Berdasarkan hasil penelitian (Atik) di Akademi Kebidanan Estu Utomo Boyolali Pada Tahun 2011, dengan judul "Hubungan Antara Mnat Masuk Jurusan DIII Kebidanan dan Motivasi Belajar dengan Prestasi Belajar Mahasiswa”. Dengan jumlah sampel 83 responden menunjukkan ada hubungan antara minat masuk dengan prestasi belajar ( $p: 0,652$, signifikasi 0,000), ada hubungan antara minat masuk dan motivasi belajar secara bersama-sama dengan prestasi belajar $(0,000<0,05)$.

Berdasarkan data pendidikan STIKES Mitra Adiguna Palembang jumlah mahasiswa D III Kebidanan tingkat II berjumlah 52 orang.

Berdasarkan uraian di atas, maka penulis tertarik untuk melakukan penelitian dengan judul

"Hubungan Antara Minat Masuk Jurusan DIII Kebidanan dan Motivasi Belajar dengan Prestasi Belajar Pada Mahasiswa D III Kebidanan Tingkat II STIKES Mitra Adiguna Palembang Tahun 2019".

\section{METODE PENELITIAN} RUANG LINGKUP PENELITIAN

Penelitian dilakukan pada mahasiswa program studi D III Kebidanan semester IV Stikes Mitra Adiguna Palembang Tahun 2019.

\section{Format Penelitian}

Penelitian inimenggunakan pendekatan kuantitatif, jenis penelitiannya cross sectional, dimana untuk mengetahui pengaruh variabel independen dan dependen yang pengukurannya dilaksanakan pada waktu yang sama (serentak).

\section{Waktu Penelitian}

Penelitian ini dilakukan pada 02 - 03 April tahun 2019.

\section{Tempat Penelitian}

Penelitian ini dilaksanakan di Stikes Mitra Adiguna Palembang Tahun 2019.

\section{Data dan Cara Pengumpulan Data Data Primer}

Pada penelitian ini data primer didapatkan dari mahasiswa semester IV di Stikes Mitra Adiguna Palembang.

\section{Data Sekunder}

Data sekunder pada penelitian ini adalah nilai semester (KHS) semester I,II, dan III mahasiswa D III Kebidanan tingkat II Stikes Mitra Adiguna Palembang.

\section{Tekhnik / Cara Pengumpulan Data}

Penelitian dilakukan dengan menyebar kuesioner minat masuk jurusan dan motivasi belajar sebagai data primer, dan dokumentasi prestasi belajar yang berupa IP dalam KHS sebagai data sekunder.

\section{Populasi dan Sampel Populasi}

Populasi adalah keseluruhan subjek penelitian. Populasi dalam penelitian ini adalah semua mahasiswa semester IV program studi D III Kebidanan Stikes Mitra 
Adiguna Palembang yang berjumlah 52 orang.

\section{Sampel}

Sampel penelitian adalah objek yang diteliti yang dianggap mewakili seluruh populasi (Notoatmodjo, 2012).

Dalam penelitian ini yang dijadikan sampel penelitian adalah total populasi yang berjumlah 52 orang.

Pengambilan sampel pada penelitian ini dengan teknik cluster random sampling, dimana sampel diambil berdasarkan kelompok kelas yang telah ditentukan dan dipilih secara random. (Notoatmodjo, 2012).

\section{Analisa Bivariat}

Analisis bivariat digunakan untuk melihat kemungkinan hubungan antara variabel independen dan variabel dependen. Pada analisis ini terdapat variabel katagorik dengan variabel katagorik, sehingga uji statistik yang digunakan adalah uji chi-square dengan batas kemaknaan dengan alpha $=0,05$ sehingga bila hasil analitik statistik $\mathrm{p}<0,05$ maka hubungan kedua variabel signifikan atau bermakna.

\section{Tekhnik Pengolahan Data}

Menurut (Hidayat, 2010) dalam proses ini pengolahan data antara lain :

\section{Editing (Pengeditan Data)}

Editing adalah upaya untuk memeriksa kembali kebenaran data yang diperoleh atau dikumpulkan. Editing dapat dilakukan pada tahap pengupulan data atau setelah data terkumpul.

2. Coding (Pengkodean)
Coding merupakan kegiatan pemberian kode numerik (angka) terhadap data yang terdiri atas beberapa kategori.

3. Data entry

Data entry adalah kegiatan memasukkan data yang telah dikumpulkan ke dalam master tabel atau data base komputer, kemudian membuat distribusi frekuensi sederhana atau dengan membuat tabel kontigensi.

\section{Melakukan Teknik Analisa}

Dalam melakukan analisa, khususnya terhadap data penelitian akan menggunakan ilmu statistik terapan yang disesuaikan dengan tujuan yang hendak dianalisis.

\section{Hasil Penelitian Dan Pembahasan Analisa Univariat}

Analisa ini dilakukan dengan menggunakan distribusi frekuensi dan presentase dari variabel independen (minat masuk jurusan, dan motivasi belajar) dan variabel dependen (prestasi belajar) data disajikan dalam bentuk tabel dan teks.

\section{Variabel Independen Minat Masuk Jurusan}

Hasil penelitian terhadap 52 responden di Stikes Mitra Adiguna Palembang Tahun 2019, dimana terdapat variabel minat masuk jurusan, dikatagorikan baik, jika skor $\geq 36,83$ dan kurang, jika skor $<36,83$. Adapun distribusi frekuensinya sebagai berikut :

Tabel 1

Distribusi frekuensi minat masuk jurusan D III Kebidanandi Stikes Mitra Adiguna PalembangTahun 2019 


\begin{tabular}{cccc}
\hline No & $\begin{array}{c}\text { Minat Masuk } \\
\text { Jurusan }\end{array}$ & Jumlah & Persentase \\
\hline 1 & Tinggi & 44 & 84,6 \\
\hline 2 & Rendah & 8 & 15,4 \\
\hline & Total & 52 & 100 \\
\hline
\end{tabular}

Tabel 3

Distribusi frekuensi Prestasi Belajar Mahasiswa di Stikes Mitra Adiguna Palembang Tahun 2019

Berdasarkan hasil penelitian didapatkan distribusi Minat masuk jurusan sebagian besar tinggi yaitu berjumlah 44(84,6\%) responden.

\section{Motivasi Belajar}

Hasil penelitian terhadap 52respondendi Stikes Mitra Adiguna Palembang Tahun 2019, dimana terdapat variabel motivasi belajar, dikatagorikan baik, jika skor $\geq 36,98$ dan kurang, jika skor $<36,98$. Adapun distribusi frekuensinya sebagai berikut:

Tabel 2

Distribusi frekuensi Motivasi Belajardi Stikes Mitra Adiguna

Palembang Tahun 2019

\begin{tabular}{cccc}
\hline No. & $\begin{array}{c}\text { Motivasi } \\
\text { Belajar }\end{array}$ & Jumlah & Persentase \\
\hline 1 & Tinggi & 45 & 86,5 \\
2 & Rendah & 7 & 13,5 \\
\hline & Total & 52 & $100 \%$ \\
\hline
\end{tabular}

Berdasarkan hasil penelitian didapatkan distribusi motivasi belajar sebagian besar baik yaitu berjumlah $45(86,5 \%)$ responden.

\section{Variabel Dependen \\ Prestasi Belajar}

Hasil penelitian terhadap 52 responden di Stikes Mitra Adiguna Palembang Tahun 2019, dimana terdapat variabel prestasi belajar, dikatagorikan baik, jika IP $\geq 2,75$ dan cukup, jika IP< 2,75. Adapun distribusi frekuensinya sebagai berikut

\begin{tabular}{lccc} 
No. & $\begin{array}{c}\text { Prestasi } \\
\text { belajar }\end{array}$ & Jumlah & Persentase \\
\hline 1 & Baik & 43 & 82,7 \\
2 & Cukup & 9 & 17,3 \\
\hline & Total & 52 & $100 \%$ \\
\hline
\end{tabular}

Berdasarkan hasil penelitian didapatkan distribusi prestasi belajar mahasiswa sebagian besar baik yaitu berjumlah $43(82,7 \%)$ responden.

\section{Analisa Bivariat}

Analisa ini dilakukan untuk mengetahui hubungan antara variabel independen (pengetahuan, persiapan fisik dan mental, dukungan keluarga, dukungan tenaga kesehatan) dengan variabel dependen (pemberian ASI). Penelitian ini dilakukan untuk melihat apakah ada hubungan antara variabel independen dan variabel dependen dengan menggunakan uji statistik Chi-Square dengan batas kemaknaan $\alpha=0,05$ sehingga bila hasil analitik statistik $\mathrm{p}<0,05$ maka hubungan kedua variabel signifikan atau bermakna.

\section{Hubungan Minat Masuk Jurusan dengan Prestasi Belajar Mahasiswa}

Penelitian ini menggunakan sampel sebanyak 52 responden mahasiswa D III Kebidanan tingkat II di Stikes Mitra Adiguna Palembang Tahun 2019. Hubungan minat masuk jurusan dengan prestasi belajar mahasiswa di rangkum pada tabel 4 dibawah ini

Tabel 4

Hubungan Minat Masuk Jurusan dengan Prestasi Belajar

Mahasiswa Stikes Mitra Adiguna Palembang Tahun 2019 
Tabel 5

\begin{tabular}{|c|c|c|c|c|c|c|c|c|}
\hline \multirow{3}{*}{$\begin{array}{c}\text { Minat } \\
\text { Masuk } \\
\text { Jurusan }\end{array}$} & \multicolumn{4}{|c|}{$\begin{array}{c}\text { Prestasi Belajar } \\
\text { Mahasiswa }\end{array}$} & \multirow{2}{*}{\multicolumn{2}{|c|}{ Total }} & \multirow{2}{*}{$\begin{array}{c}\mathrm{P} \\
\text { value }\end{array}$} & \multirow{2}{*}{$\begin{array}{c}\text { OR } \\
(95 \% \\
\text { CI })\end{array}$} \\
\hline & \multicolumn{2}{|c|}{ Baik } & \multicolumn{2}{|c|}{ Cukup } & & & & \\
\hline & $\mathrm{n}$ & $\%$ & $\mathrm{n}$ & $\%$ & $\mathrm{~N}$ & $\%$ & \multirow{3}{*}{0,002} & 16,667 \\
\hline Tinggi & 40 & 90,9 & 4 & 9,1 & 44 & 100 & & $2,862-$ \\
\hline Rendah & 3 & 37,5 & 5 & 62,5 & 8 & 100 & & 97,083 \\
\hline & 43 & 82,7 & & 17,3 & 52 & 100 & & \\
\hline
\end{tabular}

Berdasarkan tabel 4 diatas diketahui dari 44 responden yang minat masuk jurusannya tinggi sebagian besar prestasi belajarnya baiksebanyak 40 responden $(90,9 \%)$ sedangkan dari 8 responden yang minat masuk jurusannya rendah didapatkan prestasi belajarnya baik sebanyak 3 responden $(37,5 \%)$.

Dari hasil uji statistik diperoleh nilai $\mathrm{P}$ value $=0,002$ maka dapat disimpulkan ada hubungan Minat Masuk Jurusan dengan prestasi belajar mahasiswa di Stikes Mitra Adiguna Palembang Tahun 2019

Dari hasil analisis diperoleh pula nilai $\mathrm{OR}=16,667$, artinya responden yang minat masuk jurusannya tinggi memiliki peluang 16,667 kali untuk memperoleh prestasi belajar yang baik.

\section{Hubungan Motivasi Belajar dengan Prestasi Belajar Mahasiswa}

Penelitian ini menggunakan sampel sebanyak 52 responden mahasiswa D III Kebidanan tingkat II di Stikes Mitra Adiguna Palembang Tahun 2019. Hubungan motivasi belajar dengan prestasi belajar mahasiswa di rangkum pada tabel 5 dibawah ini :

\begin{tabular}{|c|c|c|c|c|c|c|c|c|}
\hline \multirow{3}{*}{$\begin{array}{l}\text { Motivasi } \\
\text { Belajar }\end{array}$} & \multicolumn{4}{|c|}{$\begin{array}{l}\text { Prestasi Belajar } \\
\text { Mahasiswa }\end{array}$} & \multicolumn{2}{|c|}{ Total } & \multirow[t]{2}{*}{$\begin{array}{c}\mathrm{P} \\
\text { value }\end{array}$} & \multirow{2}{*}{$\begin{array}{c}\text { OR } \\
(95 \% \\
\text { CI) }\end{array}$} \\
\hline & \multicolumn{2}{|c|}{ Baik } & \multicolumn{2}{|c|}{ Cukup } & & & & \\
\hline & $\mathrm{n}$ & $\%$ & $\mathrm{n}$ & $\%$ & $\mathrm{~N}$ & $\%$ & & 10,667 \\
\hline Tinggi & 40 & 88,9 & 5 & 11,1 & 45 & 100 & 0,026 & $\begin{array}{l}1,831 \\
-62\end{array}$ \\
\hline Rendah & 3 & 42,9 & 4 & 57,1 & 7 & 100 & & 113 \\
\hline
\end{tabular}

Berdasarkan tabel 5 diatas diketahui dari 45 responden yang motivasi belajarnya tinggi sebagian besar prestasi belajarnya baik sebanyak 40 responden $(88,9 \%)$ sedangkan dari 7 responden yang motivasi belajarnya rendah didapatkan prestasi belajarnya baik sebanyak 3 responden $(42,9 \%)$.

Dari hasil uji statistik diperoleh nilai $\mathrm{P}$ value $=0,013$ maka dapat disimpulkan ada hubungan Motivasi Belajar dengan Prestasi Belajar Mahasiswa di Stikes Mitra Adiguna Palembang Tahun 2019.

Dari hasil analisis diperoleh pula nilai $\mathrm{OR}=10,667$, artinya responden yang Motivasi Belajarnya tinggi memiliki peluang10,667 kali untuk emperoleh prestasi belajar yang baik. 


\section{Keterbatasan Penelitian}

Penelitian ini dilakukan pada 2 - 3 April 2019 di Stikes Mitra Adiguna Palembang. Dalam pelaksanaan penelitian ini, peneliti menyadari tidak lepas dari kekurangan dan keterbatasan yang ada meskipun telah diupayakan sebaik mungkin untuk mengatasinya. Peneliti menyadari kurangnya pengalaman dalam melakukan penelitian tentu hasilnya kurang sempurna dan banyak kekurangan.

Dalam penelitian ini, penulis menghadapi beberapa keterbatasan yang dapat mempengaruhi kondisi dari penelitian yang dilakukan. Adapun keterbatasan tersebut antara lain:

a. Peneliti hanya menggunakan kuisioner dan tidak melakukan wawancara mendalam.

b. Waktu yang tersedia untuk menyelesaikan penelitian ini relatif pendek padahal kebutuhan sampel sangat besar.

c. Dana yang dapat disediakan oleh peneliti dalam menyelesaikan penelitian ini sangat terbatas.

\section{Pembahasan}

Penelitian ini menggunakan desain Cross Sectional dimana penelitian ini hanya terbatas untuk mencari hubungan antara variabel independen (minat masuk jurusan, motivasi belajar) dengan variabel dependen (prestasi belajar) dengan menggunakan uji statistik Chi-square.

\section{Hubungan Minat Masuk Jurusan dengan Prestasi Belajar Mahasiswa}

Hasil analisis univariatdidapatkan bahwa Minat Masuk Jurusan yang tinggi sebanyak 44 responden $(84,6 \%)$, lebih banyak dibandingkan responden yang minat masuk jurusannya rendah sebanyak 8 responden $(15,4 \%)$.

Berdasarkan hasil analisis bivariat diketahui bahwa Prestasi Belajar yang baik diperoleh sebanyak 40 responden $(90,9 \%)$ yang minat masuk jurusannya tinggi. Dari hasil analisis diperoleh pula nilai $\mathrm{OR}=$ 16,667 , artinya responden yang minat masuk jurusannya tinggi memiliki peluang 16,667 kali untuk memperoleh hasil Prestasi Belajar yang baik.

Berdasarkan hasil uji statistik chi-square didapatkan nilai $\mathrm{p}$ value $=0,002$ maka dapat disimpulkan ada hubungan Minat Masuk Jurusan dengan Prestasi Belajar Mahasiswa di Stikes Mitra Adiguna Palembang Tahun 2019.

Penelitian ini sejalan dengan penelitian Kurniawati (2013) yang berjudul "Hubungan Minat Menjadi Bidan dengan Prestasi Belajar Mahasiswa D III Kebidanan Semester IV di Stikes Aisyiah Yogyakarta Tahun 2013". Berdasarkan hasil penelitian yang telah dilaksanakan, maka dapat dirumuskan kesimpulan bahwa ada hubungan yang bermakna antara minat menjadi bidan dengan prestasi belajar ( $p$ : 0,042).

Berdasarkan penelitian Arantika (2014) yang berjudul "Hubungan Minat Masuk Jurusan D III Kebidanan dan Kebiasaan Belajar dengan Prestasi Belajar Mahasiswa" maka dapat dirumuskan kesimpulan bahwa ada hubungan yang positif dan signifikan antara minat masuk program studi D III kebidanan dengan prestasi belajar mahasiswa ( $\mathrm{r}$ hitung $=0,551)$.

Hal ini di dukung oleh pernyataan Slameto (2015), yang menyatakn bahwa Minat besar sekali pengruhnya terhadap prestasi belajar, sebab dengan minat seseorang akan melakukan sesuatu yang diminatinya tersebut. Kegagalan yang dialami pelajar kebanyakan dikarenakan kurangnya minat dari pelajar itu sendiri. Bisa dikatakan minat menjadi kunci keberhasilan setelah berusaha dengan sungguh-sungguh.

Hal ini didukung oleh pernyataan (Mudjiono, 2015), Minat adalah kecenderungan yang tetap untuk memperhatikan dan mengenang beberapa kegiatan. Kegiatan yang diminati tersebut diperhatikan terus menerus yang disertai dengan rasa senang. Rasa senang dan rasa ketertarikan pada kegiatan tersebut tanpa ada yang menyuruh. Minat pada dasarnya adalah penerimaan suatu hubungan antara diri sendiri dengan sesuatu atau kegiatan diluar diri. Semakin kuat atau dekat hubungan tersebut maka semakin besar minatnya.

Hal ini sesuai dengan (Mudjiono, 2015), Minat yang besar berpengaruh terhadap belajar, karena apabila bahan pelajaran yang dipelajari tidak sesuai dengan minat siswa, siswa tidak akan belajar dengan baik. Siswa 
segan untuk belajar dan tidak memperoleh kepuasan dari pelajaran yang dipelajari.

Hal ini di dukung oleh pernyataan (Muhibbin, 2018), Dalam proses belajar siswa harus mempunyai minat atau kesukaan untuk mengikuti kegiatan pembelajaran yang berlangsung, karena dengan adanya minat akan mendorong siswa untuk menunjukkan perhatian, aktivitasnya, dan partisipasinya dalam mengikuti belajar yang berlangsung.

Berdasarkan hasil penelitian, teori pendukung peneliti berpendapat Minat masuk jurusan yang tinggi akan meningkatkanprestasi belajar mahasiswa karena dengan adanya minat akan mendorong mahasiswa untuk aktif dan lebih semangat lagi dalam belajar sehingga akan berdampak terhadap prestasi yang diperoleh mahasiswa tersebut.

\section{Hubungan Motivasi Belajar dengan Prestasi Belajar}

Hasil analisis univariat didapatkan bahwa Motivasi Belajar yang tinggi diperoleh sebanyak45 responden $(86,5 \%)$, lebih banyak dibandingkan responden yang motivasi belajarnya rendah ada 7 responden $(13,5 \%)$.

Berdasarkan hasil analisis bivariat diketahui Prestasi Belajar yang baik diperoleh sebanyak 40 responden $(88,9 \%)$ yang motivasi belajarnya tinggi. Dari hasil analisis diperoleh pula nilai OR $=10,667$, artinya responden yang motivasi belajarnya tinggi memiliki peluang 10,667, kali untuk memperoleh prestasi belajar yang baik.

Berdasarkan hasil uji statistik chisquare didapatkan nilai $\mathrm{p}$ value $=0,013$ maka dapat disimpulkan ada hubungan motivasi belajar dengan prestasi belajar mahasiswa di Stikes Mitra Adiguna Paalembang Tahun 2019.

Penelitian ini juga sejalan dengan penelitian Atik Setyaningsih (2011) yang berjudul "Hubungan Antara Minat Masuk Jurusan D III Kebidanan dan Motivasi Belajar dengan Prestasi Belajar Mahasiswa". Berdasarkan hasil penelitian yang dilaksanakan, maka dapat dirumuskan kesimpulan bahwa ada hubungan motivasi belajar dan prestasi belajar dengan hasil ( $p$ :0,066).

Hal ini didukung oleh pernyataan Lestari (2015) yang menyatakan bahwa hubungan antara motivasi dan prestasi belajar yaitu, Motivasi merupakan suatu aktivitas yang menempatkan seseorang atau suatu kelompok yang mempunyai kebutuhan tertentu dan pribadi untuk bekerja menyelesaikan tugasnya. Motivasi merupakan kekuatan, dorongan kebutuhan, tekananan, dan mekanisme psikologis yang dimaksudkan merupakan akumulasi faktorfaktor internal dan eksternal. Faktor internal bersumber dari dalam diri individu sendiri, sedangkan faktor eksternal bersumber dari luar indvidu. Faktor internal dapat pula disebut sebagai akumulasi aspek-aspek internal individu seperti kepribadian, intelegensi, ciri-ciri fisik, kebiasaan, kesadaran, minat, bakat, kemauan, spirit, antusiasme, dan sebagainya. Faktor eksternal bersumber dari lingkungan fisik, sosial, tekanan dan regulasi keorganisasian. Faktor internal dan eksternal itu berinteraksi dan diaktualisasikan oleh individu dalam bentuk kapasitas kerja.

Hal ini sesuai dengan (Mudjiono, dimyati. 2015), Motivasi dipandang sebagai dorongan mental yang menggerakkan dan mengarahkan perilaku manusia, termasuk perilaku belajar. Kekuatan mental tersebut berupa keinginan, perhaatian, kemauan, atau cita-cita. Kekuatan mental tersebut dapat tergolong rendah atau tinggi. Ada tiga komponen utama dalam motivasi, yaitu : kebutuhan, dorongan, dan tujuan. Kebutuhan terjadi apabila ada individu yang merasa ada ketidakseimbangan antara apa yang ia miliki dan yang ia harapkan. Dorongan merupakan kekuatan mental untuk melakukan kegiatan dalam rangka memenuhi harapan. Tujuan mengarahkan pada perilaku belajar.

Hal ini didukung oleh pernyataan (Sadirman, 2014), Motivasi merupakan daya upaya yang mendorong seseorang untuk melakukan sesuatu. Daya penggerak tersebut berasal dari dalam dan dari luar subjek untuk melakukan aktivitas-aktivitas tertentu demi mencapai suatu tujuan.

Berdasarkan hasil penelitian, teori pendukung peneliti berpendapat Motivasi belajar yang tinggi akan meningkatkanprestasi belajar mahasiswa karena dengan adanya motivasi artinya mahasiswa memiliki kekuatan, dorongan kebutuhan untuk belajar dan menyelesaikan tugasnya dengan baik. Semakin tinggi motivasi yang dimiliki oleh mahasiswa maka 
akan semakin baik pula prestasi yang dapat diperolehnya.

\section{KESIMPULAN DAN SARAN Kesimpulan}

Berdasarkan penelitian terhadap 52respondenyang telah dilakukan di Stikes Mitra Adiguna Palembang Tahun 2019 maka dapat disimpulkan sebagai berikut :

1. Dari hasil Chi-square didapatkan pvalue $=0,002<0,05$ hal ini menunjukkan bahwa ada hubungan antara Minat Masuk Jurusan dengan Prestasi Belajar Mahasiswa di Stikes Mitra Adiguna Palembang Tahun 2019.

2. Dari hasil Chi-square didapatkan pvalue $=0,013<0,05$ hal ini menunjukkan bahwa ada hubungan antara Motivasi Belajar dengan Prestasi Belajar Mahasiswa di Stikes Mitra Adiguna Palembang Tahun 2019.

\section{Saran}

\section{Bagi Institusi Pendidikan}

Penelitian ini menyajikan informasi sebagai referensi dan bahan masukan untuk peningkatan mutu pendidikan terkait dengan metode, sarana prasarana dan kegiatankegiatan yang dapat menumbuhkan minat mahasiswa untuk menjadi bidan, meningkatkan motivasi belajar mahasiswa, serta meningkatkan prestasi belajar mahasiswa.

\section{Bagi Mahasiswa}

Sebagai masukan bagi mahasiswa bahwa minat dan motivasi belajar dapat mempengaruhi prestasi belajar sehingga mereka berusaha untuk menumbuhkan, meningkatkan, dan mengembangkannya agar hasil belajar yang dicapai sesuai dengan tujuan yang diharapkan.

\section{Bagi Peneliti Selanjutnya}

Sebagai bahan acuan penelitian yang akan datang dan disarankan bagi peneliti selanjutnya untuk meneliti faktor lain yang berhubungan dengan prestasi belajar selain minat masuk jurusan D III bidan dan motivasi belajar untuk memperkaya informasi bagi berbagai pihak.

\section{DAFTAR PUSTAKA}

Ariyanti, Ita. 2010. Pengaruh Minat dan Motivasi belajar dan Prestasi Belajar Mahasiswa Program Studi
Pendidikan Akuntansi Universitas Negeri Semarang. Semarang.

Departemen Pendidikan Nasional. 2003. Undang-Undang sistem pendidikan nasional. Jakarta.

Dimyati, Mudjiono. 2015. Belajar dan Pembelajaran. Jakarta : Rineka Cipta.

Hidayat. 2010. Metode Penelitian Kesehatan Paradigma Kuantitatif. Jakarta : Health Book

IBI dan AIPKIND. 2012. Peran Bidan. Jakarta

Kementrian Pendidikan Nasional. 2011. Jumlah Perguruan Tinggi Kesehatan. Jakarta : Kemendiknas RI

Keputusan Menteri Kesehatan RI NO. 369/MENKES/SK/III/2007. 2007. Tentang Standar Profesi Bidan. Jakarta : Kemenkes RI

Kurniawati, Dwi Riska. 2013. "Hubungan Minat Menjadi Bidan Dengan Prestasi Belajar Mahasiswa DIII Kebidanan Semester IV STIKES AISYIAH YOGYAKARTA". Yogyakarta.

Lataima, Agustina. 2014. "Hubungan Minat Dengan Prestasi Belajar Mata Kuliah Asuhan Kebidanan $2 A$ Semester II Di STIKES AISYIAH YOGYAKARTA". Yogyakarta..

Muhibbin, Syah. 2013. Psikologi Pendidikan. Bandung : PT. Remaja Rosda Karya.

Notoatmodjo, Soekidjo, Dr, Prof. 2012. Metodologi Penelitian Kesehatan. Jakarta : PT Rineka Cipta.

Oemar, Hamalik. 2014. Proses Belajar Mengajar. Jakarta : PT Bumi Aksara

Pratiwi, Arantika Meidya. 2014. "Hubungan Minat Masuk Program Studi DIII Kebidanan Dan Kebiasaan Belajar Dengan Prestasi Belajar Mahasiswa”. Surakarta.

Pusdiknakes. 2013. Prestasi Belajar Mahasiswa. 
Sadirman. 2015. Interaksi dan Motivasi Belajar Mengajar. Jakarta : PT. Raja Grafindo Persada

Setiyaningsih, Atik. 2013. "Hubungan Antara Minat Masuk Jurusan DIII Kebidanan Dan Motivasi Belajar Dengan Prstasi Belajar Mahasiswa”. Boyolali.

Slameto. 2015. Belajar dan Faktor-faktor yang Mempengaruhi. Jakarta : Rineka Cipta

Sugiyono. 2016. Metodelogi Penelitian Kuantitatif, Kualitatif, dan $R \& D$. Bandung : Alfabeta. 